OPEN ACCESS

Edited by:

Quande Qin,

Shenzhen University, China

Reviewed by:

Wang Jianliang,

China University of Petroleum, China

Huaping Sun,

Jiangsu University, China

*Correspondence:

Hui Hu

hui.hu@whu.edu.cn

Yufeng Wu

yufeng.wu.17@ucl.ac.uk

Specialty section:

This article was submitted to

Sustainable Energy Systems and

Policies,

a section of the journal

Frontiers in Energy Research

Received: 25 June 2021 Accepted: 30 August 2021

Published: 06 October 2021

Citation:

Hu H, Lin J, Liu L and Wu Y (2021)

Cognitive Biases in Understanding the Influence of Shale Gas Exploitation:

From Environmental and

Economic Perspectives.

Front. Energy Res. 9:730526. doi: 10.3389/fenrg.2021.730526

\section{Cognitive Biases in Understanding the Influence of Shale Gas Exploitation: From Environmental and Economic Perspectives}

\author{
Hui $H u^{1,2 *}$, Jingtong $\operatorname{Lin}^{2}, L u L i u^{2}$ and Yufeng $W u^{3 *}$ \\ ${ }^{1}$ Economic Development Research Centre, Wuhan University, Wuhan, China, ${ }^{2}$ School of Economics and Management, Wuhan \\ University, Wuhan, China, ${ }^{3}$ Department of Geography, University College London, London, United Kingdom
}

People have higher expectations for shale gas exploitation. However, the promotion of large-scale shale gas exploitation does not seem to be as good as it seems, since the extraction technology - hydraulic fracturing - harms the environment, which causes cognitive biases. This paper reviews studies that estimate the environmental and economic influence of the fracturing process in the U.S. and China to help people better understand the shale gas exploitation. It summarizes the methodological issues and results of main projections. There are shared problems in evaluating the influence of shale gas development due to limited identification methods, data sources and advancing exploitation technologies. Little research values the environmental influence of shale gas development in social benefit or economic benefit. Though varies significantly across various plays and parameter compared with conventional gases, previous researches indicate that water use for shale gas development will not affect the local water supply vastly, and the ultimate influence relies on the water management method. Moreover, compared with conventional natural gas and other energy resources, freshwater consumption about shale gas exploration is decreasing with the progress of exploration technology, while its life-cycle GHG emissions are greater in the long term.

Keywords: shale gas exploitation, environmental influence, estimation, energy production, economic influence

\section{INTRODUCTION}

Compared to conventional energy sources like coal, natural gas is expected to be cheaper and have less greenhouse gas (GHG) emissions (Jacoby et al., 2011). As the unconventional natural gas distributed in shale, burning shale gas does not produce much GHG (Liss, 2014; Weijermars, 2014). Because of the improvement of exploitation technologies, which is also known as hydraulic fracturing or "fracking", energy companies can extract shale gas under the ground at a depth that was impossible in the past. The U.S. remains the largest explorer and producer of shale gas (EIA, 2013).

The work that the U.S. has carried out in shale gas and shale oil leads other countries to find its possibility for energy supply. According to the U.S. Energy Information Administration, China is the single largest depository of natural gas all over the world (EIA, 2013) and China started its shale gas production in 2012 . However, less than $2 \%$ of the total production of the natural gas reserve has been explored till 2019, which seems that the exploration is in a slow progress. 


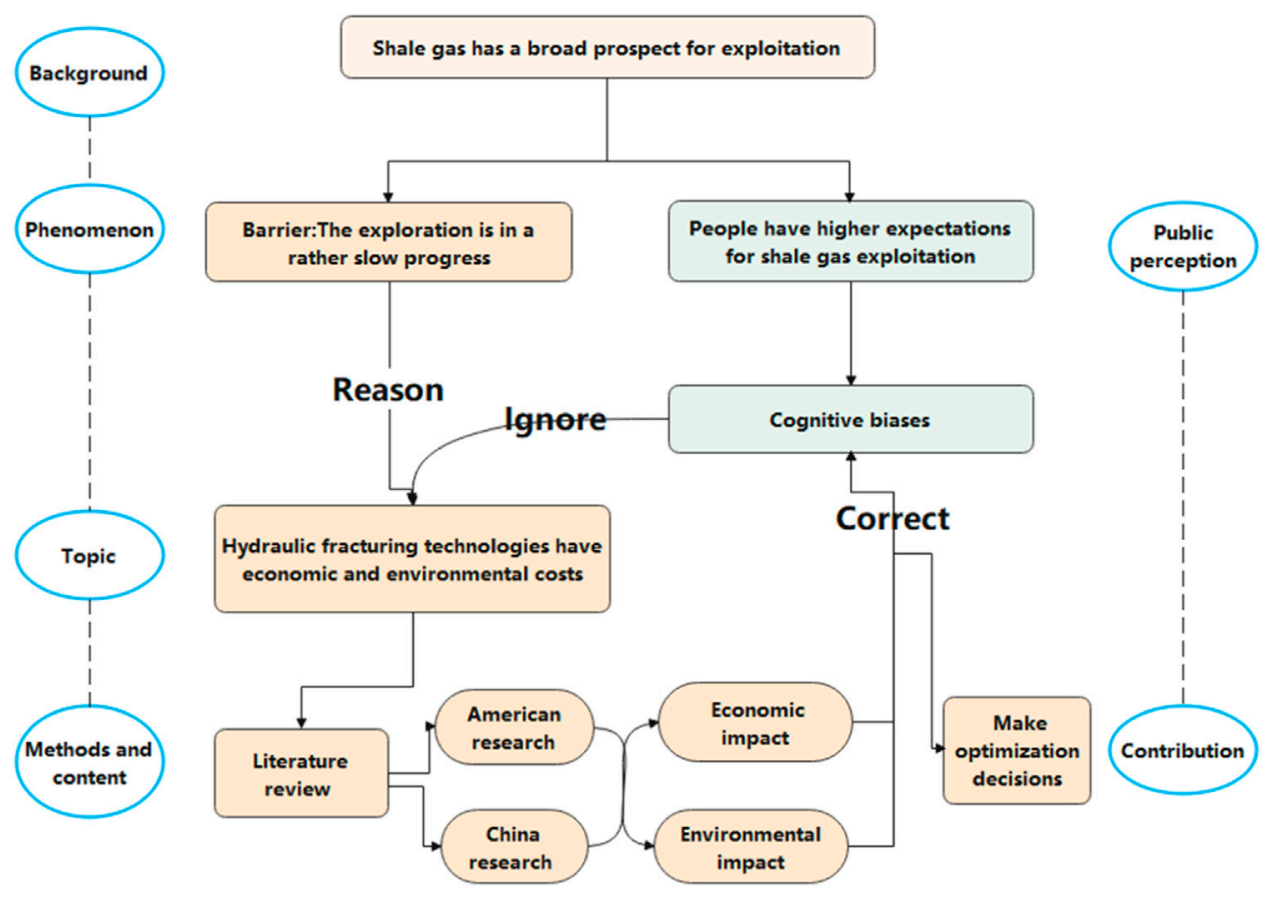

FIGURE 1 | General research frame.

A potential barrier of this slow process is the environmental and economic costs for hydraulic fracturing process (Healy, 2012; Wan et al., 2014). The exploitation techniques and the environmental and economic impact raise important questions about the shale gas exploitation opportunity (Boudet et al., 2014; Cotton et al., 2014; Davis and Fisk, 2014; Andersson-Hudson et al., 2016). Initial studies on this topic address the qualitative analysis of shale gas extraction, exhibiting a series of factors that should be considered when applying hydraulic fracturing, without measuring those impacts in figures (Sovacool, 2014). Then with the progress of fracturing practice, there are a growing number of studies to analyze its impacts in a quantitative method, estimating the level of influence.

In particular, based on the existence of cognitive biases, this article believes that people tend to amplify the benefits of shale gas exploitation due to less GHG emissions, while ignoring the environmental and economic costs caused by technologies ( $\mathrm{Li}$ et al., 2020).

This review aims to summarize studies that indicated the environmental or economic influence of fracturing technologies for drilling shale gas. Specifically, this review focused on the studies in the U.S. and China, to see the numeric conclusions and trends of environmental and economic impact in shale gas development, despite methodological and regional variations in references.

To give a systematic summary of estimating environmental impacts, this study first introduces how hydraulic fracturing work does and the most influenced aspect in every phase during the working process. After that, this review introduces the environmental elements instead of the drilling step, in order that the specific impact on each environmental element could be understood more clearly (Figure 1).

Summaries draw from previous estimations indicate that though varies significantly across various scenarios compared with conventional natural gas resources, water use for shale gas development can be better controlled through efficient water management (Barbot et al., 2013). Freshwater consumption of shale gas exploration is smaller than that of conventional fuels, with a dwindling trend due to the advancing exploration technology, while its lifetime GHG emissions may be greater due to the lasting greenhouse effect of methane. Few researchers have tried to quantify the potential earthquake threats brought by shale gas drilling so far (Sun et al., 2021b). The paper helps people have a better understanding of the shale gas exploitation process in reality. This study would be helpful not only to researchers and operators of gas exploitation companies working to incorporate environmental and economic impacts into decision-making processes but to some public sectors.

\section{MATERIALS AND METHODOLOGY}

\section{Hydraulic Fracturing Technology}

Shale gas is a gas generated by the remains of sea animals. For millions of years, due to the movement of the earth's crust, layers of organic matter sink to depths of several kilometers. Under this anaerobic environment and high pressure, layers of organic matter are converted into natural gas and trapped in rocks. Shale gas is contained in natural gas in the holes of shale gas formations. 
Every continent in the world reserves a large amount of shale gas, but only North America produces large-scale shale gas because the gas burying shale is too deep down in the ground. The shale gas mining methods has not been economic and attractive until the prices of natural gas and other fuels were raised (EIA, 2013). Horizontal drilling and hydraulic fracturing are non-commercial until new techniques are applied in the U.S. They enable extracting shale gas at depths of several kilometers.

Hydraulic fracturing allows companies to extract shale gas and shale oil that are previously inaccessible under the ground, which is of crucial importance since the demand for energy rises rapidly after the Industrial Revolution. Currently, hydraulic fracturing has been used over a million times in the U.S. While breaking the shale and releasing the gas, hydraulic fracturing has risks and receives controversial remarks (Geny, 2010; Spellman, 2012; Ahmadi and John, 2015; Milt and Armsworth, 2017).

The first step of exploitation is to set up a rig and vertical drilling. When the drill bit reaches the shale formations, it turns $90^{\circ}$ and continues to drill horizontally. Then the steel tube is laid in the borehole dilled, which is called the casing. Concrete holds the casing in place to prevent material from leaking into or out of the borehole. To allow gas flowing to the surface, a performing gun is put down into the casing to perforate on the steel casing, causing holes connected in the casing and cracks in shale.

To produce shale gas, the crack in the shale must be expanded and this step is known as hydraulic fracturing. This involves injecting pressurized liquids into boreholes and shale fractures. Fracturing fluid consists of water, sands and various chemical agents which are used to increase the density of water, sterilize and dissolve minerals in the shale. Pressurized liquid increases pressure inside the casing, causing a rupture in cracks and forming new breaches (Brasch, 2012). In this step, the large amount of water and sands are undoubtedly burdens of local natural resources (Brantley et al., 2013; Eaton, 2013) and the liquid full of chemicals may pollute underground water through cracks and its branches (Vengosh et al., 2014; Darrah et al., 2014). Fracturing fluid may also change the pressure of the ground and loosen the soils, posing a potential hazard of the earthquake (Hitzman, 2013; Zoback, 2015).

Once hydraulic fracturing is performed, pressurized liquids are removed from the borehole. When the water pressure is removed from the drilling well, the small sand grains keep the fracture open. Then the pressure of the casing will be restored and shale gas flows through the hole and high to the ground. However, a small amount of transporting shale gas will escape into the atmosphere during the extracting and transfer to carbon dioxide in the end (Howarth et al., 2011; Huangfu et al., 2020).

Moreover, though it will be extracted from the ground first to collect shale gas, once a gas well dries up, fracturing fluid will be pumped back into the casing and locked in the deep. The major risk of this step is environmental problems (He et al., 2013; Vengosh et al., 2013). Hydraulic fracturing does not only use lots of water but also turning them into toxic liquid with the chemical component, which is irreversible and incapable to purify at present. Innumerable underground water sources have suffered from fracturing fluid in the U.S. and so far no investigation to show what is the long-term presentation of those locked up liquid. It is also inevitable to pollute the soil and plants around the drilling area (Yuan et al., 2015).

\section{Methodology}

The existing literature on this topic can be divided into categories as follows. Most studies investigate hydraulic fracturing's impact on the environment, with some specific section on public welfare. Their conclusions are based on the technical theory and materials used in the drilling process. These studies focus on identifying and analyzing the categories of influence more than on their specific level.

Many studies focus on one section of the whole drilling process and provide the measurement of potential influence due to the resources or generation. The main contents of these papers can be focused on one shale gas oilfield, a specific extraction plan or even an imputation model. Every well is the only one in the field of the productivity and consumption of hydraulic fracturing fluid, injected freshwater and wastewater. Most studies provide a sensitivity analysis, indicating indigenous climate or geographic impacts to variations in water and carbon influence.

Within studies that calculate the exact amount of GHG emission generated or water body impact, the life-cycle environmental influence of shale gas is compared with that of conventional resources or local energy supply. In this comparative way, these studies started to emphasize the influence of shale gas exploration from an economic perspective, rather than a single number.

Only a few references provide economic and monetary evaluations for the expected environmental influence due to hydraulic fracturing technology. The results of these references rely heavily on the resources of the dataset and the local geographic condition, and the impact of added earthquake risks is scarcely considered.

To keep the point in focus, this study will only introduce those studies with at least a quantitative analysis in economical detail, or those with valuable insights or innovations. In the meantime, more specific and recent papers have been prioritized in the paper.

\section{MAIN PROJECTIONS IN LITERATURE}

\section{Water Consumption and Contamination in the Exploitation of Shale Gas}

\section{Complexity in Estimation and Decreasing Trends}

The potential effects of shale gas operation on water resources triggered an intense public debate on hydraulic fracturing, since they may lead to environmental and public health threats (Soeder and Kappel, 2009; Kargbo et al., 2010; Gregory et al., 2011; Vidic et al., 2013; Brittingham et al., 2014; Mauter et al., 2014). Freshwater influence and accessibility are affected by local climate and water supply and demand. Conditions can be severe in places that are susceptible to drought. (Brittingham et al., 2014). Evaluation and estimation of the water impact from hydraulic fracturing are therefore essential considering the overall benefit of shale gas development. 
TABLE 1 | Most relevant studies on water usage and wastewater on shale gas development.

\begin{tabular}{|c|c|c|c|c|c|}
\hline References & Boundaries & Scenarios & $\begin{array}{l}\text { Geographic } \\
\text { area }\end{array}$ & $\begin{array}{l}\text { Projection } \\
\text { period }\end{array}$ & Projected influence \\
\hline $\begin{array}{l}\text { Nicot and } \\
\text { Scanlon (2012) }\end{array}$ & $\begin{array}{l}\text { Water flooding, and fracking, } \\
\text { drilling, injection of water into } \\
\text { an oil reservoir }\end{array}$ & $\begin{array}{l}\text { Water use for fracking for shale-gas } \\
\text { production obtained indirectly from the } \\
\text { Railroad Commission (RRC) through a } \\
\text { vendor (IHS) database }\end{array}$ & $\begin{array}{l}\text { Barnett } \\
\text { Shale, TX } \\
\text { Haynesville } \\
\text { Shale, TX } \\
\text { Eagle Ford, TX }\end{array}$ & The year 2012 & $\begin{array}{l}\text { Barnett Shale, TX } 10600 \text { water use per } \\
\text { well (cubic meters) } \\
\text { Haynesville Shale, TX } 21500 \text { water use } \\
\text { per well (cubic meters) } \\
\text { Eagle Ford, TX } 16100 \text { water use per well } \\
\text { (cubic meters) }\end{array}$ \\
\hline $\begin{array}{l}\text { Kargbo et al. } \\
(2010)\end{array}$ & & & $\begin{array}{l}\text { Marcellus } \\
\text { Shale, PA }\end{array}$ & The year 2010 & $\begin{array}{l}7700-38000 \text { cubic meters water use per } \\
\text { well }\end{array}$ \\
\hline $\begin{array}{l}\text { Dale et al. } \\
\text { (2013) }\end{array}$ & $\begin{array}{l}\text { life-cycle stage water } \\
\text { consumption }\end{array}$ & $\begin{array}{l}\text { Self-reported data from two operators in } \\
\text { the Marcellus play }\end{array}$ & $\begin{array}{l}\text { Marcellus } \\
\text { Shale, PA }\end{array}$ & $\begin{array}{l}\text { The year } \\
\text { 2011-2012 }\end{array}$ & $\begin{array}{l}2011-2012 \text { well has mean impacts of } 2.2 \\
\times 10^{6} \mathrm{~kg} \mathrm{CO}_{2} \text {-eq, } 2.2 \times 10^{7} \mathrm{MJ} \text { of } \\
\text { primary energy, and consumption of } 8.2 \\
\times 10^{4} \text { barrels of water }\end{array}$ \\
\hline
\end{tabular}

Greenhouse gases emission in exploitation of shale gas

What adds to the complexity of the estimation of water body impact is that water varies due to multiple reasons, such as geographic conditions, the type of shale gas bed, the assumed efficiency of power plants, the water management, the tracking method of baseline water chemistry data and even the environmental oversight policy (Elbel and Britt, 2000; Holditch, 2007). Moreover, local water availability and competing demands also affect water use for shale gas (Nicot and Scanlon, 2012). Most references explain their core assumptions used in estimation, and some important element of them is stressed out in the following part.

As water-intensive energy technologies become more widespread, there are also water treatment or reuse plans intended to reduce the strain on water resources. The advancing water management leads to changing results of estimations, which presents a continually decreasing trend in water usage by 2014 . However, better handling and treating water may be at the cost of burdening carbon impact.

\section{Significantly Various Results in Water Consumption}

In the literature (Table 1), water usage in shale gas exploitation across various geologic basins is complex. . The estimated water demand ranges from 1,400 to 33,900 cubic meters per shale-gas well (Nicot and Scanlon, 2012; Clark et al., 2013; Goodwin et al., 2014; Scanlon et al., 2014) and 8,177-9,009 cubic meters (Scanlon et al., 2014; Horner et al., 2016).

Historical data in references indicates the significance of drilling date, well borehole orientation, and target hydrocarbon on hydraulic fracturing water volumes, also, it accounts for the wide range of estimates (Nicot and Scanlon, 2012; Gallegos and Varela, 2014). The environmental effects are different with the change of target oil, gas reservoirs, the amount of water use, geologic and hydrologic settings. (Mauter et al., 2014; Gallegos et al., 2015). Though there are findings that state the reuse of hydraulic fracturing wastewater may alleviate the negative impact, however, this solution is difficult to implement in some areas since local regulatory structures in water treatment are rather complicated (Romo and Janoe, 2012).

\section{Suggested Greater Actual Emission From Shale Gas Drilling}

Although natural gas contributes to alleviating global warming for less GHG emissions, most people know little about the emission of shale gas extraction. The GHG emission of shale gas may contain two patterns. One is the direct emissions of $\mathrm{CO}_{2}$, which is from end-use consumption, another is the indirect emissions of $\mathrm{CO}_{2}$, which is from materials and fuels. It is well recognized in the references that the indirect emissions of $\mathrm{CO}_{2}$ are smaller than those from the direct ones (Hayhoe et al., 2002; Santoro et al., 2011). Therefore, for shale gas, the GHG emission is mostly made up of direct $\mathrm{CO}_{2}$ emissions and fugitive methane emissions.

The carbon footprint of shale gas is estimated to be lower than coal (Laurenzi and Jersey, 2013). However, the U.S. National Research Council warned that emissions from shale gas drilling can be larger than from conventional ones (Kling, 2010). Methane can make greater global warming effect on atmospheric aerosols than previously assumed according to the modeling (Shindell et al., 2009), even small leakages lead to considerable influence. Since methane is a strong GHG (Hultman et al., 2011), the carbon footprint (GHG emissions per low heating value of fuel) for shale gas is larger than that for conventional ones (Xie et al., 2021).

To see the trade-off of using shale gas as unconventional natural gas and the strong global warming effect of leaked methane, estimating the influence of GHG emission for the hydraulic fracturing process is therefore interesting.

\section{The Greater Long-Term Carbon Footprint of Shale Gas Exploration}

Apart from time range and projection methods, the estimation of GHG also relies particularly on the technical background document issued by the government and the location where the study takes place.

The technical report on GHG emissions was first drawn up in 1996 by the EPA (Harrison et al., 1996), which served as the basis for the national GHG inventory for the following decade. Nevertheless, the report only analyzed the facilities offered by 
TABLE 2 | Most relevant studies on GHG emission on shale gas development.

\begin{tabular}{|c|c|c|c|}
\hline References & Boundaries & Scenarios & Projected influence \\
\hline $\begin{array}{l}\text { Karion et al. } \\
\text { (2013) }\end{array}$ & $\begin{array}{l}\text { the Uintah Basin }(4,800 \text { gas wells and } \\
\text { nearly } 1,000 \text { oil wells are } \\
\text { concentrated) }\end{array}$ & $\begin{array}{l}\text { Mass balance approach in atmospheric } \\
\text { measurements }\end{array}$ & $\begin{array}{l}\text { Methane emissions of } 55 \pm 15 \times 103 \mathrm{~kg} / \mathrm{h} \text { from a } \\
\text { natural gas and oil production field }\end{array}$ \\
\hline Heath et al. (2014) & $\begin{array}{l}\text { GHG emissions of shale gas for } \\
\text { electricity generation }\end{array}$ & & Range from around $440-760 \mathrm{~kg} \mathrm{CO} \mathrm{CO}_{2} \mathrm{e} / \mathrm{MWh}$ \\
\hline $\begin{array}{l}\text { Laurenzi and } \\
\text { Jersey (2013) }\end{array}$ & $\begin{array}{l}\text { life cycle assessment (LCA) of GHG } \\
\text { emission from Marcellus shale gas }\end{array}$ & $\begin{array}{l}\text { Exxon Mobil field data and IHS Energy Well Production } \\
\text { database }\end{array}$ & $\begin{array}{l}\text { Marcellus shale gas life cycle yields } 466 \mathrm{~kg} \mathrm{CO} \text { eq/ } \\
\text { MWh on average; The total emission amount } \\
\text { associated with extraction phases shall be therefore } \\
5.45 \mathrm{~kg} \mathrm{CO} \mathrm{CO}_{2} \mathrm{eq} / \mathrm{MWh} \text { on average. The power plant is } \\
\text { where most of the gas is burned }\end{array}$ \\
\hline Li et al. (2019) & $\begin{array}{l}\text { Conventional dehydration process } \\
\text { and Stripping gas dehydration } \\
\text { process }\end{array}$ & $\begin{array}{l}\text { The hybrid life cycle inventory }(\mathrm{LCl}) \text { model consists of } \\
\text { process-based methods to evaluate the } \\
\text { environmental impacts associated with shale gas } \\
\text { dehydration }\end{array}$ & $\begin{array}{l}\text { Increasing impacts from shale gas loss negate the } \\
\text { gains from the savings in utility and electricity. A case } \\
\text { with more trays and lower solvent purity is preferred in } \\
\text { the environment }\end{array}$ \\
\hline
\end{tabular}

voluntarily participated companies, not on random sampling or a comprehensive evaluation of the actual extraction process (Kirchgessner et al., 1997). The distribution of emissions may be very different according to the region (Rusco, 2011).

In 2010, the first update EPA report on emission factors was launched, noting that some emission factors had potentially been understated in the 1996 report. Howarth et al. (2011) used the 2010 version reported emission factors and data from two shale gas formations and three tight-sand gas formations in the U.S. to estimate the GHG footprints accumulated of shale gas extraction. They were the first to publish a study calculating the emissions from well completion, liquid unloading, gas processing, transport, storage, and distribution losses and routine venting and equipment leaks.

In 2013 the EPA's emissions factors for calculating methane emissions from liquid unloading, unconventional completions with hydraulic fracturing, and re-fracturing of natural gas wells were raised down (EPA, 2013). It is driven by a report prepared by the oil and gas industry which stated that methane emissions from these three extraction steps were at least half less than the EPA's 2011 estimation (Shires and Lev-On, 2012). However, Karion, et al. (2013) found that results from the top-down approach of oil and gas production regions were estimates too low (Karion et al., 2013). The average leak rate they calculate is at least 1.8 times greater than the bottom-up estimate. It was very likely that the methodology that the public sectors used to account for fugitive methane emissions has some problems and this result in the lack of accurate and reliable estimates of associated emissions. Table 2 shows the most relevant studies evaluating the GHG on shale gas development.

There are also studies trying to better monitor and control the global warming influence of shale gas extraction. Having a balance between the contradictory objectives is crucial for process optimization (Karion et al., 2013). Gao and You, (2015) propose a mixed-integer linear fraction programming (MILFP) model to address the optimal design and operations of water supply chain networks for shale gas production, reaching economic optimization and less GHG emission. It states that reverse osmosis (RO) technology is the best way to onsite treatment wastewater with outstanding economic and environmental performance. Li et al. (2019) offered a framework to assess the economic and environmental impact of shale gas dehydration. Especially, they discovered cases about optimal economic performance is suboptimal in environmental aspects and vice versa under different process parameters ( $\mathrm{Li}$ et al., 2019).

Other references look into GHG emission as the water management cost from the gas extraction process. Clark et al. (2012) reported that a single fracturing job needs about $18,000 \mathrm{~L}$ (4,771 gallons) of diesel (Clark et al., 2012). And roughly 11,000 L (3,000 gallons) of diesel (Clark et al., 2012) and about 186,000 kWh of electric energy is needed for transportation and municipal wastewater treatment (Goldstein and Smith, 2002; EPA, 2010; $E P A$, 2013). It seems that wastewater management needs considerable energy and therefore contributes most to the total GHG emission. Absar et al. (2018) pointed out a trade-off between water and carbon impacts on the simple basis that energy is required for the treatment of water. The overall footprint of the shale gas production process are determined by the choice of wastewater management scenario. They calculated that a reduction of 49 percent in total water consumption or a 28 percent reduction in the water scarcity footprint in the production process can be achieved at a cost of a 38 percent increase in global warming potential (Absar et al., 2018).

\section{Major Estimation in Literature Less Feasibility and More Risk for Shale Gas Development}

As the largest energy consumer in the world, China faces enormous energy needs under its efforts to make far-flung economic growth, while the government intends to reduce coal dependence and adopt an energy strategy that is responsible for society and economy (Wan et al., 2014). Replacing with natural gas therefore will make long-term advantages in reducing energy production costs and limit the extent where China relies on exported oil supplies.

Most studies in China in this field use economic features to evaluate the influence of shale gas exploitation. Primary researches concentrates on China's geological conditions and 
exploitation technologies (Hua et al., 2009; Wang et al., 2009; Chen et al., 2011; Wei et al., 2012). Some discussed the promotional policy of the China shale gas exploitation (Zhao et al., 2011; Farah and Tremolada, 2013; Zhang and Jiang, 2013), mainly focusing on analyzing the strategy based on the successful experience of the U.S.

Many references stated the key elements resulting in the difference of estimated environmental impact between the two countries. The geological conditions in China are much more complicated (Teng and Liu, 2013; Chen et al., 2017; Ma et al., 2021). China's shale basins are different from the ones in the United States, which located in harsh terrains and mountainous (Yu et al., 2013). China has the more complicated geological conditions and lacks environmental management laws and regulations, which will face more environmental risks caused by shale gas exploration compared to U.S. (Liu et al., 2021).

Moreover, even though the shale gas resources in China are abundant, water availability could limit shale gas commercialization successfully. The production sites of shale gas usually lack water resources (Ministry of Water Resources, 2011), making it hard to reach the economic scale of shale gas exploration on the condition of not wasting local water in some reserves-rich areas.

$\mathrm{Yu}$ concluded the socioeconomic impacts and risks encountered in the process of shale gas exploration in China, including the risk of uncertain estimated shale gas resources potential, limited technological experience and researches, exploration plan without long-term vision, and lack of water availability for exploration (Yu, 2015). However, as The Shale Gas Development Plan (2011-2015) said, to select suitable areas for shale gas exploration, the main criteria are the depth, resources, surface, and storage conditions of shale gas formations. The impacts studies conducted from the environmental perspective on China's shale gas exploitation are therefore very important.

\section{Limited Data Resources and Optimal Trial}

Results of existing studies in the U.S. are not readily suitable to China, because shale gas production in China and the U.S. is different in many aspects, such as geographical features, water accessibility, materials quantities, drilling equipment use, energy supplies, and drilling technology.

Basing on the first horizontal well in Sichuan China, Chang et al. (2014a) built a hybrid LCI model to measure the energy use, water use and emissions of the shale gas exploitation process. Combining average fugitive and flaring data from U.S. plays and the methane content data of shale gas in China, the estimated shale-to-well GHG emissions were 5,500 metric tons of carbon dioxide equivalents $\left(\mathrm{CO}_{2} \mathrm{e}\right)$ (Zhao and Yang, 2015). Chang et al. (2014b) concluded that by 2020 , the total consumption of direct water from 2013 to 2020 could reach 20-720 million cubic meters for 20-100 billion cubic meters shale gas exploitation in China. Furthermore, Chang et al. (2014a) and Wang et al. (2018) provided the basic data about energy use and direct water consumption of well drilling, hydraulic fracturing, well cementing, and well completion for later researches to look on. There was a need, however, to develop and consider in more developed technologies, for example,

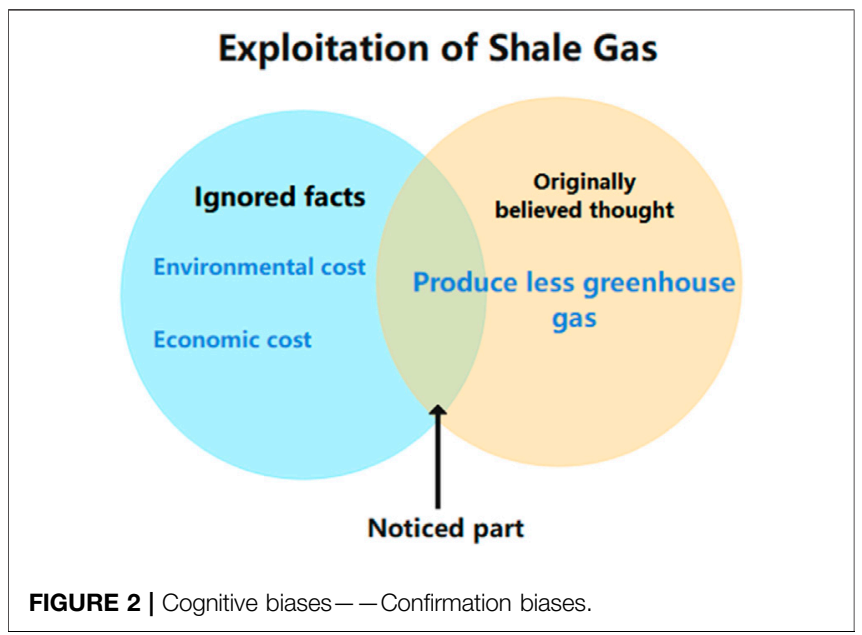

fracturing flow-back management, and the evaluation of water impact did not include groundwater contamination (Mohan et al., 2013).

Along with the development of Chinese shale gas industry, references later had more sufficient data and were able to consider impacts in a wider range of aspects. In Sichuan Basin, one of China's most promising shale gas basins, freshwater withdrawal per well in the surface for the hydraulic fracturing ranged between 20,000 and 30,000 cubic meters (Yang et al., 2015; Yu, 2015). Unlike most of the published results, Xiao et al. employed water footprint (WF) methodology to evaluate the impact of regional shale gas development on local water resources. The water intensity (WI) of shale gas extraction is in the range of $0.3-9.9 \mathrm{~kg}$ per cubic meters shale gas produced. They also found that although shale gas production needed a large amount of water, it would not affect the local water supply significantly.

Ren et al. built up a bi-objective programming model to work out the balance between economic and environmental goals. Results showed that the proportion of freshwater usage increases when decision maker wants to decrease the economic costs and fix the satisfaction degree for uncertain constraints. As a result, the environmental costs increase (Ren et al., 2019).

\section{DISCUSSION}

\section{Cognitive Biases on Understanding the Influence of Shale Gas Exploitation}

In the understanding of shale gas Exploitation, people often have some cognitive biases. Cognitive biases are systematic patterns of deviation from norm or rationality in judgment, which affect us in many areas of life, such as social situations, memory recall, what we believe, and our behaviors (Korteling and Toet, 2020; Schumm, 2021). Confirmation bias is a bias of belief that people tend to seek out or interpret information in a way that confirms their preconceived notions and ideas. In other words, people attempt to preserve their existing beliefs by focus on information that confirms those beliefs and discounting information that 
could challenge them. In terms of energy exploitation (Cafferata et al., 2021), people often believe that natural gas can produce less GHG compared with traditional energy and can better prevent environmental pollution (Wang et al., 2021). As a result, people tend to have better expectations for the exploitation of shale gas. Such preconceived belief reinforces the advantages of shale gas exploitation but ignores the environmental and economic costs of hydraulic fracturing, which is often a reflection of cognitive bias (see Figure 2).

By studying the current situation of natural gas exploitation technology in the United States and China, this paper concludes the economic and environmental challenges encountered in shale gas exploitation, which can better understand the impact of shale gas exploitation and correct people's original understanding deviation.

\section{Variation Between Different Studies on Shale Gas Exploration}

Estimation differs in data and modelling; fundamentally relies on the geographical characters in a specific area.

First, the estimation boundaries and therefore the most contributing phrases of the fracturing process are different. In the U.S., most shale gas well is developed nearby the conventional gas and oil wells. Therefore, well site investigation and preparation were assumed to have negligible water impacts and GHG emissions and they were excluded from the analysis. In China, on the contrary, well sites preparation takes up a large amount of additional energy consumption. Specifically, several standards documents give different data on drilling pad area, water impoundment capacity, and onsite road width and thickness. So it might not be suggested to simply compare the estimated results of different regions, but to look into the most influential and influenced factors in each case.

Second, researchers in China rely on open data and industrial background instructions to conduct researches. There are different sources, from volunteer collection and official regulations, in American practice, since the shale gas exploration has been mature for a longer time. We can see that early Chinese researcher had to use data from foreign cases to estimate the volume of indigenous water use. Moreover, the estimation mythology applied in the estimation in North America shows greater variety and flexibility in time frames and scenarios. There is a gap in the boundaries of database and evaluation mythology in Chinese shale gas exploitation practice.

However, Chinese researchers seem to start translating the results on an economic and monetary basis sooner. There have been a few attempts to transform the influence of GHG emission and water footprint into actual economic cost, and discussions on the trade-off between environmental and economic benefits in Chinese studies.

More mature technologies in the U.S. should be applied to China as the emergence of large-scale shale gas exploitation, such as water-based drilling, multi-stage fracturing, fracturing flow back management, drilling mud treatment. Governmental authorities should draft some industrial standards and regulations to guide drilling practices, and also, the full technological-economic-environmental effects of the process should be assessed completely.

\section{Shared Problems in Evaluating the Exact Influence of Shale Gas Development}

There are also shared problems in evaluating the exact influence of shale gas development.

First, the contamination from shale gas exploration cannot be precisely assessed since it is difficult to identify the effect of pure shale gas exploration on water pollution. For example, the presence of naturally occurring saline groundwater in areas of shale gas development poses challenges for quantifying contamination from active shale gas development, including the ability to distinguish naturally occurring groundwater salinization from anthropogenic sources of groundwater pollution.

There is a debate about the possibility of water contamination, and the extent to which it exists depends on the availability of baseline water chemistry data in aquifers. One method to fill the data gap is to build novel geochemical and isotopic tracers for confirming or refuting evidence for contamination. Therefore, studies should focus more on water contamination mechanisms for further investigation.

Another question is the uncertainty of estimation due to changing gas development technology. For example, by improving engineering controls, many of the risks mentioned in the literature are more likely to mitigate. Therefore, new primary data are needed to better understand the water consumption from shale gas transport and processing. To ensure the estimation of possible influence up to date and serves to policymaking, it is important to keep up with the changes brought by advanced solutions. In future studies, a more detailed comparative analysis of system boundaries, multiple uncertain factors and data set of different case studies should be provided. Additionally, better recognize the influence of technological progress on the water management of shale gas exploration could help us make the water management process more efficient.

\section{CONCLUSIONS AND FUTURE STUDIES}

The environmental influence of shale gas development and fracturing technologies make up a growing area of research (Sun et al., 2021a). However, there is still little research that can interpret the emission and pollution volume into social benefit or economic benefit accounting, to give more specific answers when considering the implementation of shale gas exploration in a certain area. In the past few years, many studies have been conducted in this attempt especially on the trade-off between carbon emission and water treatment the optimization of water management. Some researchers are trying to measure the environmental influence of shale gas development from per well unit to energy return unit and make a comparison with results of conventional gas resources. 
In this case, the influence of shale gas development on the local environment is small and is dwindling with the progress of the water treatment method. Yet the impact on possible wastewater injection-induced earthquakes is too complex to be taken into account.

The long-term impact estimation of shale gas development also lacks investigation and discussion. Scientists have long known methane has greater global warming potential than carbon dioxide. The footprint for shale gas is larger than that for oil or conventional gas when viewed on any time horizon but particularly for over 20 years. The environmental effects for shale gas production are worth researching in the long run.

Overall, due to the existence of cognitive biases, people tend to amplify the advantages of shale gas exploitation because of less GHG emissions, while ignoring the environmental and economic costs in the process. To analyze the comprehensive economic-environmental impact of shale gas development further in time shall be important for decision-making and should be improved by further research.

\section{REFERENCES}

Absar, S. M., Boulay, A.-M., Campa, M. F., Preston, B. L., and Taylor, A. (2018). The tradeoff between water and carbon footprints of Barnett Shale gas. J. Clean. Prod. 197, 47-56. doi:10.1016/j.jclepro.2018.06.140

Ahmadi, M., and John, K. (2015). Statistical evaluation of the impact of shale gas activities on ozone pollution in North Texas. Sci. Total Environ. 536, 457-467. doi:10.1016/j.scitotenv.2015.06.114

Andersson-Hudson, J., Knight, W., Humphrey, M., and O’Hara, S. (2016). Exploring support for shale gas extraction in the United Kingdom. Energy Policy 98, 582-589. doi:10.1016/j.enpol.2016.09.042

Barbot, E., Vidic, N. S., Gregory, K. B., and Vidic, R. D. (2013). Spatial and temporal correlation of water quality parameters of produced waters from devonian-age shale following hydraulic fracturing. Environ. Sci. Technol. 47, 2562-2569. doi:10.1021/es304638h

Boudet, H., Clarke, C., Bugden, D., Maibach, E., Roser-Renouf, C., and Leiserowitz, A. (2014). "Fracking" controversy and communication: Using national survey data to understand public perceptions of hydraulic fracturing. Energy Policy 65, 57-67. doi:10.1016/j.enpol.2013.10.017

Brantley, S. L., Yoxtheimer, D., Arjmand, S., Grieve, P., Vidic, R., Abad, J. D., et al. (2014). In Water Resource Impacts During Unconventional Shale Gas Development: The Pennsylvania Experience. Int. J. Coal Geol. 126, 140-156.

Brasch, W. M. (2012). Fracking Pennsylvania: flirting with disaster. California: Greeley \& Stone publishers.

Brittingham, M. C., Maloney, K. O., Farag, A. M., Harper, D. D., and Bowen, Z. H. (2014). Ecological Risks of Shale Oil and Gas Development to Wildlife, Aquatic Resources and their Habitats. Environ. Sci. Technol. 48 (19), 11034-11047. doi:10.1021/es5020482

Cafferata, A., Dávila-Fernández, M. J., and Sordi, S. (2021). Seeing what can(not) be seen: Confirmation bias, employment dynamics and climate change. J. Econ. Behav. Organ. 189, 567-586. doi:10.1016/ j.jebo.2021.07.004

Chang, Y., Huang, R., and Masanet, E. (2014a). The energy, water, and air pollution implications of tapping China's shale gas reserves. Resour. Conservation Recycling 91, 100-108. doi:10.1016/j.resconrec.2014.07.015

Chang, Y., Huang, R., Ries, R. J., and Masanet, E. (2014b). Shale-to-well energy use and air pollutant emissions of shale gas production in China. Appl. Energ. 125, 147-157. doi:10.1016/j.apenergy.2014.03.039

Chen, S., Zhu, Y., Wang, H., Liu, H., Wei, W., and Fang, J. (2011). Shale gas reservoir characterisation: A typical case in the southern Sichuan Basin of China. Energy 36 (11), 6609-6616. doi:10.1016/j.energy.2011.09.001

Chen, Y., He, L., Guan, Y., Lu, H., and Li, J. (2017). Life cycle assessment of greenhouse gas emissions and water-energy optimization for shale gas supply chain planning based on multi-level approach: Case study in Barnett, Marcellus,

\section{DATA AVAILABILITY STATEMENT}

The datasets generated for this study are available on request to the corresponding author.

\section{AUTHOR CONTRIBUTIONS}

$\mathrm{HH}$ and YW finish the research and paper writing. LL and JL are responsible for data collection and analysis. JL works with the other authors for the Empirical Results Section.

\section{ACKNOWLEDGMENTS}

The authors are grateful to the editor and reviewers for their insightful comments. Special thanks to NNSFC project (71603193 and 71974151), Dr. Qingyuan Zhou and Dr. Jiafeng Li.

Fayetteville, and Haynesville shales. Energ. Convers. Manag. 134, 382-398. doi:10.1016/j.enconman.2016.12.019

Clark, C. E., Han, J., Burnham, A., Dunn, J. B., and Wang, M.EVS (2012). Life-cycle analysis of shale gas and natural gas. Off. Scientific Tech. Inf. Tech. Rep.1, 15-20. doi: $10.2172 / 1044520$

Clark, C. E., Horner, R. M., and Harto, C. B. (2013). Life Cycle Water Consumption for Shale Gas and Conventional Natural Gas. Environ. Sci. Technol. 47 (20), 11829-11836. doi:10.1021/es4013855

Cotton, M., Rattle, I., and Van Alstine, J. (2014). Shale gas policy in the United Kingdom: An argumentative discourse analysis. Energy Policy 73, 427-438. doi:10.1016/j.enpol.2014.05.031

Dale, A. T., Khanna, V., Vidic, R. D., and Bilec, M. M. (2013). Process Based LifeCycle Assessment of Natural Gas from the Marcellus Shale. Environ. Sci. Technol. 47 (10), 5459-5466. doi:10.1021/es304414q

Darrah, T. H., Vengosh, A., Jackson, R. B., Warner, N. R., and Poreda, R. J. (2014). Noble gases identify the mechanisms of fugitive gas contamination in drinkingwater wells overlying the Marcellus and Barnett Shales. Proc. Natl. Acad. Sci. USA 111 (39), 14076-14081. doi:10.1073/pnas.1322107111

Davis, C., and Fisk, J. M. (2014). Energy abundance or environmental worries? Analyzing public support for fracking in the United States. Rev. Pol. Res. 31 (1), 1-16. doi:10.1111/ropr.12048

Eaton, T. T. (2013). Science-based decision-making on complex issues: Marcellus shale gas hydrofracking and New York City water supply. Sci. Total Environ. 461-462, 158-169. doi:10.1016/j.scitotenv.2013.04.093

EIA (2013). Technically Recoverable Shale Oil and Shale Gas Resources: An Assessment of 137 Shale Formations in 41 Countries outside the United States. Washington, DC: U.S. Energy Information Administration.

Elbel, J., and Britt, L. (2000). Fracture treatment design. Reserv. Stimul., 1-50.

EPA (2010). Greenhouse gas emissions reporting from the petroleum and natural gas industry, background technical support document. Washington, DC: US Environmental Protection Agency.

EPA (2013). Inventory of US greenhouse gas emissions and sinks: 1990-2011. Washington DC: United States Environmental Protection Agency, 505 .

Farah, P. D., and Tremolada, R. (2013). A comparison between shale gas in China and unconventional fuel development in the United States: Health, Water and Environmental risks. FEEM Working, 95, 2013 . Paper No.

Gallegos, T. J., Varela, B. A., Haines, S. S., and Engle, M. A. (2015). Hydraulic fracturing water use variability in the $U$ nited $S$ tates and potential environmental implications. Water Resour. Res. 51 (7), 5839-5845. doi:10.1002/2015wr017278

Gallegos, T. J., and Varela, B. A. (2014). Trends in hydraulic fracturing distributions and treatment fluids, additives, proppants, and water volumes applied to wells drilled in the United States from 1947 through 2010: Data analysis and comparison to the literature. United States: USGS. 
Gao, J., and You, F. (2015). Shale Gas Supply Chain Design and Operations toward Better Economic and Life Cycle Environmental Performance: MINLP Model and Global Optimization Algorithm. ACS Sust. Chem. Eng. 3 (7), 1282-1291. doi:10.1021/acssuschemeng.5b00122

Geny, F. (2010). Can unconventional gas be a game changer in European gas markets. Oxf. Inst. Energ Stud., 46.

Goldstein, R., and Smith, W. (2002). Water \& sustainability, Vol. 4. United States: US electricity consumption for water supply \& treatment-the next half century; EPRI.

Goodwin, S., Carlson, K., Knox, K., Douglas, C., and Rein, L. (2014). Water Intensity Assessment of Shale Gas Resources in the Wattenberg Field in Northeastern Colorado. Environ. Sci. Technol. 48 (10), 5991-5995. doi:10.1021/es404675h

Gregory, K. B., Vidic, R. D., and Dzombak, D. A. (2011). Water Management Challenges Associated with the Production of Shale Gas by Hydraulic Fracturing. Elements 7, 181-186. doi:10.2113/gselements.7.3.181

Harrison, M. R., Shires, T. M., Wessels, J. K., and Cowgill, R. M. (1996). Methane Emissions from the Natural Gas Industry, Vol. 1. Washington, DC: U.S. Environmental Protection Agency, Office of Research and Development. Executive Summary.

Hayhoe, K., Kheshgi, H. S., Jain, A. K., and Wuebbles, D. J. (2002). Substitution of natural gas for coal: Climatic effects of utility sector emissions. Clim. Change 54 (1), 107-139. doi:10.1023/a:1015737505552

He, C., Zhang, T., and Vidic, R. D. (2013). Use of abandoned mine drainage for the development of unconventional gas resources. Disruptive Sci. Tech. 1 (4), 169-176. doi:10.1089/dst.2013.0014

Healy, D. (2012). Hydraulic Fracturing or 'Fracking': A Short Summary of Current Knowledge and Potential Environmental Impacts. Ireland: Environ. Protect. Agency.

Heath, G. A., O’Donoughue, P., Arent, D. J., and Bazilian, M. (2014). Harmonization of initial estimates of shale gas life cycle greenhouse gas emissions for electric power generation. Proc. Natl. Acad. Sci. U S A. 111 (31), E3167-E3176. doi:10.1073/pnas.1309334111

Hitzman, M. (2013). Induced Seismicity Potential in Energy Technologies. United States: American Physical Society.

Holditch, S. A. (2007). Hydraulic fracturing. Petroleum Engineering Handbook: Production Operations Engineering. Richardson, TX: Society of Petroleum Engineers, 323-366.

Horner, R. M., Harto, C. B., Jackson, R. B., Lowry, E. R., Brandt, A. R., Yeskoo, T. W., et al. (2016). Water use and management in the bakken shale oil play in north Dakota. Environ. Sci. Technol. 50 (6), 3275-3282. doi:10.1021/ acs.est.5b04079

Howarth, R. W., Santoro, R., and Ingraffea, A. (2011). Methane and the greenhouse-gas footprint of natural gas from shale formations. Climatic Change 106 (4), 679-690. doi:10.1007/s10584-011-0061-5

Hua, S., WenLi, J., and RuiKang, B. (2009). Shale gas assessment methodology and its application: A case study of the western Sichuan depression. Nat. Gas Ind. 29, 130-134.

Huangfu, Z., Hu, H., Xie, N., Zhu, Y.-Q., Chen, H., and Wang, Y. (2020). The heterogeneous influence of economic growth on environmental pollution: Evidence from municipal data of China. Pet. Sci. 17 (4), 1180-1193. doi:10.1007/s12182-020-00459-5

Hultman, N., Rebois, D., Scholten, M., and Ramig, C. (2011). The greenhouse impact of unconventional gas for electricity generation. Environ. Res. Lett. 6, 044008. doi:10.1088/1748-9326/6/4/044008

Jacoby, H. D., O'Sullivan, F. M., and Paltsev, S. (2011). The influence of shale gas on U.S. energy and environmental policy. United States: European University Institute. EUI working paper.

Kargbo, D. M., Wilhelm, R. G., and Campbell, D. J. (2010). Natural gas plays in the marcellus shale: Challenges and potential opportunities. Environ. Sci. Technol. 44 (15), 5679-5684. doi:10.1021/es903811p

Karion, A., Sweeney, C., Pétron, G., Frost, G., Michael Hardesty, R., Kofler, J., et al. (2013). Methane emissions estimate from airborne measurements over a western United States natural gas field. Geophys. Res. Lett. 40 (16), 4393-4397. doi:10.1002/grl.50811

Kirchgessner, D. A., Lott, R. A., Michael Cowgill, R., Harrison, M. R., and Shires, T. M. (1997). Estimate of methane emissions from the U.S. natural gas industry. Chemosphere 35 (6), 1365-1390. doi:10.1016/s0045-6535(97) 00236-1

Kling, C. L. (2010). Hidden costs of energy: unpriced consequences of energy production and use. Environ. Health Perspect. 119 (3), al38.

Korteling, J. E., and Toet, A. (2020). "Cognitive Biases," in Reference Module in Neuroscience and Biobehavioral Psychology (Amsterdam, Netherlands: Elsevier). doi:10.1016/b978-0-12-809324-5.24105-9

Laurenzi, I. J., and Jersey, G. R. (2013). Life cycle greenhouse gas emissions and freshwater consumption of Marcellus shale gas. Environ. Sci. Technol. 47 (9), 4896-4903. doi:10.1021/es305162w

Li, J., Hu, H., Li, X., Jin, Q., and Huang, T. (2020). Economic benefit of shale gas exploitation based on back propagation neural network. Ifs 39 (6), 8823-8830. doi:10.3233/jifs-189279

Li, W., Zhuang, Y., Zhang, L., Liu, L., and Du, J. (2019). Economic evaluation and environmental assessment of shale gas dehydration process. J. Clean. Prod. 232, 487-498. doi:10.1016/j.jclepro.2019.05.361

Liss, W. E. (2014). Impacts of shale gas advancements on natural gas utilization in the United States. Energ. Tech. 2 (12), 953-967. doi:10.1002/ente.201402061

Liu, R., Wang, J., and Lin, L. (2021). Water scarcity footprint assessment for China's shale gas development. Extractive Industries Soc. 8, 100892. doi:10.1016/j.exis.2021.02.012

Ma, X., Wang, H., Zhou, S., Shi, Z., and Zhang, L. (2021). Deep shale gas in china: geological characteristics and development strategies. Energ. Rep. 7 (6), 1903-1914. doi:10.1016/j.egyr.2021.03.043

Mauter, M. S., Alvarez, P. J. J., Burton, A., Cafaro, D. C., Chen, W., Gregory, K. B., et al. (2014). Regional variation in water-related impacts of shale gas development and implications for emerging international plays. Environ. Sci. Technol. 48 (15), 8298-8306. doi:10.1021/es405432k

Milt, A. W., and Armsworth, P. R. (2017). Performance of a cap and trade system for managing environmental impacts of shale gas surface infrastructure. Ecol. Econ. 131, 399-406. doi:10.1016/j.ecolecon.2016.09.016

Ministry of Water Resources (2011). Bulletin of Flood and Drought Disasters in China. Beijing, China: Water and Power Press.

Murali Mohan, A., Hartsock, A., Bibby, K. J., Hammack, R. W., Vidic, R. D., and Gregory, K. B. (2013). Microbial Community Changes in Hydraulic Fracturing Fluids and Produced Water from Shale Gas Extraction. Environ. Sci. Technol. 47 (22), 13141-13150. doi:10.1021/es402928b

Nicot, J.-P., and Scanlon, B. R. (2012). Water use for shale-gas production in Texas, U.S. Environ. Sci. Technol. 46 (6), 3580-3586. doi:10.1021/es204602t

Ren, K., Tang, X., Jin, Y., Wang, J., Feng, C., and Höök, M. (2019). Bi-objective optimization of water management in shale gas exploration with uncertainty: A case study from Sichuan, China. Resour. Conservation Recycling 143, 226-235. doi:10.1016/j.resconrec.2019.01.003

Romo, C., and Janoe, J. (2012). Regulatory regimes for recycling produced and frac flowback water. New York. Social Science Research Network. Available at SSRN 2124696.

Rusco, F. W. (2011). Federal Oil and Gas Leases: Opportunities Exist to Capture Vented and Flared Natural Gas, Which Would Increase Royalty Payments and Reduce Greenhouse Gases: Report to Congressional Requesters. US: US Government Accountability Office.

Santoro, R., Howarth, R. W., and Ingraffea, T. (2011). Life cycle greenhouse gas emissions inventory of Marcellus shale gas in Technical report of the Agriculture, Energy, \& Environment Program. Ithaca, NY: Cornell University.

Scanlon, B. R., Reedy, R. C., and Nicot, J.-P. (2014). Comparison of water use for hydraulic fracturing for unconventional oil and gas versus conventional oil. Environ. Sci. Technol. 48 (20), 12386-12393. doi:10.1021/es502506v

Schumm, W. R. (2021). Confirmation bias and methodology in social science: An editorial. Marriage Fam. Rev. 57 (4), 285-293. doi:10.1080/01494929.2021.1872859

Shindell, D. T., Faluvegi, G., Koch, D. M., Schmidt, G. A., Unger, N., and Bauer, S. E. (2009). Improved attribution of climate forcing to emissions. Science 326 (5953), 716-718. doi:10.1126/science.1174760

Shires, T., and Lev-On, M. (2012). Characterizing pivotal sources of methane emissions from unconventional natural gas production: Summary and analysis of API and ANGA survey responses. Final Rep. 1, 6-9.

Soeder, D. J., and Kappel, W. M. (2009). Water resources and natural gas production from the Marcellus Shale. US Geol. Surv. Fact Sheet 2009- 3032, 6. doi:10.3133/fs20093032 
Sovacool, B. K. (2014). Cornucopia or curse? Reviewing the costs and benefits of shale gas hydraulic fracturing (fracking). Renew. Sust. Energ. Rev. 37, 249-264. doi:10.1016/j.rser.2014.04.068

Spellman, F. R. (2012). Environmental Impacts of Hydraulic Fracturing. Florida: CRC Press.

Sun, H., Edziah, B. K., Kporsu, A. K., Sarkodie, S. A., and Taghizadeh-Hesary, F. (2021a). Energy efficiency: The role of technological innovation and knowledge spillover. Technol. Forecast. Soc. Change 167, 120659. doi:10.1016/ j.techfore.2021.120659

Sun, H., Edziah, B. K., Sun, C., and Kporsu, A. K. (2021b). Institutional quality and its spatial spillover effects on energy efficiency. Socio-econ Plan. Sci., 101023. doi:10.1016/j.seps.2021.101023

Teng, J. W., and Liu, Y. (2013). An analysis of reservoir formation, potential productivity and environmental pollution effect of shale gas in China. China Geol. 40, 1-30.

Vengosh, A., Jackson, R. B., Warner, N., Darrah, T. H., and Kondash, A. (2014). A critical review of the risks to water resources from unconventional shale gas development and hydraulic fracturing in the United States. Environ. Sci. Technol. 48 (15), 8334-8348. doi:10.1021/es405118y

Vengosh, A., Warner, N., Jackson, R., and Darrah, T. (2013). The effects of shale gas exploration and hydraulic fracturing on the quality of water resources in the United States. Proced. Earth Planet. Sci. 7, 863-866. doi:10.1016/ j.proeps.2013.03.213

Vidic, R. D., Brantley, S. L., Vandenbossche, J. M., Yoxtheimer, D., and Abad, J. D. (2013). Impact of shale gas development on regional water quality. Science 340 (6134), 1235009. doi:10.1126/science.1235009

Wan, Z., Huang, T., and Craig, B. (2014). Barriers to the development of China's shale gas industry. J. Clean. Prod. 84, 818-823. doi:10.1016/ j.jclepro.2014.04.073

Wang, J., Liu, M., Bentley, Y., Feng, L., and Zhang, C. (2018). Water use for shale gas extraction in the Sichuan Basin, China. J. Environ. Manage. 226, 13-21. doi:10.1016/j.jenvman.2018.08.031

Wang, S., Chen, G., and Dong, D. (2009). Accumulation conditions and exploitation prospect of shale gas in the Lower Paleozoic Sichuan Basin. Nat. Gas Ind. 29, 51-58.

Wang, Y., Hu, H., Dai, W., and Burns, K. (2021). Evaluation of industrial green development and industrial green competitiveness: Evidence from Chinese urban agglomerations. Ecol. Indicators 124, 107371. doi:10.1016/ j.ecolind.2021.107371

Wei, C., Wang, H., Sun, S., Xiao, Y., Zhu, Y., and Qin, G. (2012). "Potential Investigation of Shale Gas Reservoirs, Southern China," in SPE Canadian Unconventional Resources Conference (Calgary, Alberta, Canada: Society of Petroleum Engineers), 10. doi:10.2118/162828-ms
Weijermars, R. (2014). US shale gas production outlook based on well roll-out rate scenarios. Appl. Energ. 124, 283-297. doi:10.1016/j.apenergy.2014.02.058

Xie, N., Hu, H., Fang, D., Shi, X., Luo, S., and Burns, K. (2021). An empirical analysis of financial markets and instruments influencing the low-carbon electricity production transition. J. Clean. Prod. 280, 124415. doi:10.1016/ j.jclepro.2020.124415

Yang, H., Huang, X., Yang, Q., Tu, J., Li, S., Yang, D., et al. (2015). Water requirements for shale gas fracking in Fuling, Chongqing, Southwest China. Energ. Proced. 76, 106-112. doi:10.1016/j.egypro.2015.07.862

$\mathrm{Yu}$, S. (2015). Evaluation of socioeconomic impacts on and risks for shale gas exploration in China. Energ. Strategy Rev. 6, 30-38. doi:10.1016/j.esr.2014.11.006

Yu, T., Deng, G., Yuan, Y., Li, H., Xia, W., and Zhang, H. (2013). Environmental challenges and suggestions in shale gas development. Environ. Prot. Oil. Gas Fields 23 (5), 56-58.

Yuan, J., Luo, D., Xia, L., and Feng, L. (2015). Policy recommendations to promote shale gas development in China based on a technical and economic evaluation. Energy Policy 85, 194-206. doi:10.1016/j.enpol.2015.06.006

Zhang, X., and Jiang, X. (2013). Inspiration practices and experiences of U.S. shale gas industry development to China. China Energ 35, 17-19.

Zhao, J., Fang, C. Q., Zhang, J., Wang, L., and Zhang, X. X. (2011). Evaluation of China shale gas from the exploration and development of North America shale gas. J. Xi'an Shiyou Univ. Nat. Sci. Ed. 26, 1-7. (in Chinese).

Zhao, X., and Yang, Y. (2015). The current situation of shale gas in Sichuan, China. Renew. Sust Energ Rev. 50, 653-664.

Zoback, M. (2015). Managing the Risks of Triggered Seismicity. US: American Association for the Advancement of Science 2014 Annual Meeting.

Conflict of Interest: The authors declare that the research was conducted in the absence of any commercial or financial relationships that could be construed as a potential conflict of interest.

Publisher's Note: All claims expressed in this article are solely those of the authors and do not necessarily represent those of their affiliated organizations, or those of the publisher, the editors and the reviewers. Any product that may be evaluated in this article, or claim that may be made by its manufacturer, is not guaranteed or endorsed by the publisher.

Copyright (c) $2021 \mathrm{Hu}$, Lin, Liu and Wu. This is an open-access article distributed under the terms of the Creative Commons Attribution License (CC BY). The use, distribution or reproduction in other forums is permitted, provided the original author(s) and the copyright owner(s) are credited and that the original publication in this journal is cited, in accordance with accepted academic practice. No use, distribution or reproduction is permitted which does not comply with these terms. 